\title{
Polymerization of lignosulfonates by the laccase-HBT (1-hydroxybenzotriazole) system improves dispersibility
}

\author{
Endry Nugroho Prasetyo ${ }^{a}$, Tukayi Kudanga ${ }^{a}$, Lars Østergaard ${ }^{b}$, Jorge Rencoret ${ }^{c}$, Ana Gutiérrez $^{\mathrm{c}}$, \\ José C. del Río ${ }^{c}$, J. Ignacio Santos ${ }^{\mathrm{d}}$, Lidia Nieto ${ }^{\mathrm{d}}$, Jesús Jiménez-Barbero ${ }^{\mathrm{d}}$, Angel T. Martínez ${ }^{\mathrm{d}}$,
} Jiebing Li ${ }^{\mathrm{e}}$, Göran Gellerstedt ${ }^{\mathrm{e}}$, Stéphane Lepifre ${ }^{\mathrm{f}}$, Carla Silva ${ }^{\mathrm{g}}$, Su Yeon Kim ${ }^{\mathrm{g}}$, Artur Cavaco-Paulo ${ }^{\mathrm{g}}$, Bente Seljebakken Klausen $^{h}$, Bjart Frode Lutnaes ${ }^{\text {h }}$, Gibson S. Nyanhongo ${ }^{\mathrm{a}, *}$, Georg M. Guebitz ${ }^{\mathrm{a}}$

\footnotetext{
${ }^{a}$ Graz University of Technology, Institute of Environmental Biotechnology, Petersgasse 12/1, A-8010 Graz, Austria

${ }^{\mathrm{b}}$ Novozyme A/S, Bagsvaerd, Denmark

' Instituto de Recursos Naturales y Agrobiología de Sevilla, CSIC, P.O. Box 1042, E-41080 Seville, Spain

${ }^{\mathrm{d}}$ Centro de Investigaciones Biológicas, CSIC, Ramiro de Maeztu 9, E-28040 Madrid, Spain

${ }^{\mathrm{e}}$ Royal Institute of Technology, KTH, Department of Fibre and Polymer Technology, SE-100 44, Stockholm, Sweden

${ }^{\mathrm{f}}$ Granit SA, Rue du Grand-Chêne 5, 1003 Lausanne, Switzerland

${ }^{\mathrm{g}}$ Department of Textile Engineering, Campus deAzurém, University of Minho, Guimarães, Portugal

${ }^{\mathrm{h}}$ Borregaard Corporate Research, P.O. Box 162, 1701 Sarpsborg, Norway
}

\section{A R T I C L E I N F O}

\section{Article history:}

Received 12 November 2009

Received in revised form 8 January 2010

Accepted 14 January 2010

Available online 21 February 2010

\section{Keywords:}

Calcium lignosulfonates

Laccase

Enzymatic modification

Dispersion

Polymerization

\begin{abstract}
A B S T R A C T
The ability of laccases from Trametes villosa (TvL), Myceliophthora thermophila (MtL), Trametes hirsuta (ThL) and Bacillus subtilis (BsL) to improve the dispersion properties of calcium lignosulfonates 398 in the presence of HBT as a mediator was investigated. Size exclusion chromatography showed an extensive increase in molecular weight of the samples incubated with TvL and ThL by $107 \%$ and $572 \%$ from $28400 \mathrm{Da}$ after $17 \mathrm{~h}$ of incubation, respectively. Interestingly, FTIR spectroscopy, ${ }^{13} \mathrm{C}$ NMR and Py-GC/ MS analysis of the treated samples suggested no substantial changes in the aromatic signal of the lignosulfonates, a good indication of the ability of TVL/ThL-HBT systems to limit their effect on functional groups without degrading the lignin backbone. Further, the enzymatic treatments led to a general increase in the dispersion properties, indeed a welcome development for its application in polymer blends.
\end{abstract}

(c) 2010 Elsevier Ltd. All rights reserved.

\section{Introduction}

Lignin, the second most abundant polymer on Earth constituting $30 \%$ of non-fossil organic carbon, is currently under-utilized (Boerjan et al., 2003). Industrial lignins constitute the main byproducts of the pulp and paper industry regarded as waste material, imposing disposal problems and their major applications have been limited to providing fuel for firing the pulping boilers (Mohan and Karthikeyan, 1997). Only approximately $2 \%$ of the lignins are used commercially ( 1 million tons/year of lignosulfonates and less than 100,000 tons/year of kraft lignins) (Gargulak and Lebo, 2000; Gosselink et al., 2004; Lora and Glasser, 2002). However, over the recent years there has been a renewed interest in using lignin as a renewable raw material. This is partly due to new stringent environmental waste management regulations together with the de-

\footnotetext{
* Corresponding author. Tel.: +43 3168738404; fax: +43 3168738819 .

E-mail addresses: gnyanhongo@yahoo.com, g.nyanhongo@tugraz.at (G.S. Nyanhongo).
}

mand for replacement of oil based products with renewable materials and the new possibilities offered by emerging technologies. Consequently, investigations into increasing the application of lignin in existing and novel polymer blends for mortar, construction materials, adhesives, biodegradable plastics, polyurethane copolymers, paints, dye dispersants, in pesticides and printed circuit boards (Sena-Martins et al., 2008; Stewart, 2008; Lora and Glasser, 2002; Hüttermann et al., 2001; Kosbar et al., 2001), are increasing.

Nevertheless, massive exploitation of lignin is hampered by its huge physico-chemical heterogeneity owing to its inherent variety of aromatic units, inter-unit linkages, functional groups, and molecular size (Vázquez et al., 1999; Glasser and Sarkanen, 1989; Li et al., 1997). This is a result of both the heterogeneity of this plant polymer and its degradation during the pulping process resulting in a polydisperse material (Dence and Lin, 1992) which has high interfacial tension and lacks interfacial adhesion properties, making it difficult to achieve desired degree of dispersion in polymer blends (Cazacu et al., 2004). Most lignin polymer blends 
have been reported to be immiscible due to low entropy (Flory, 1953 ) indicating that the ability of lignin to mix strongly depends on its active properties (Ekeberg et al., 2006). For example, increasing lignin concentration in thermoplastics and rubber blends negatively affects the tensile force and melt flow index of the product (Alexy et al., 2000), while its polydispersity limits its addition between $5 \%$ and $10 \%$ the level of the resin weight in adhesive synthesis (Turunen et al., 2003). In short, the deterioration of the mechanical properties of all polymer blends where lignin has been used, is attributed to the poor adhesion and dispersion of the lignin particles which create defects that act as stress concentrators (El Mansouri and Salvado, 2006). Therefore, industrial applications of lignins require modifications to improve its dispersion properties among other physico-chemical characteristics.

In line with this demand, in this study, the effect of laccasemediator treatment on dispersion properties of lignosulfonates was investigated and correlated to chemical changes of the polymer. Lignosulfonates are highly cross-linked anionic polymers in which the essentially hydrophobic backbone is rendered hydrophilic by substitution with sulfonate groups (Askvik et al., 2001). In the presence of mediators, laccases (benzenediol: oxygen oxidoreductases, EC.1.10.3.2) can also oxidize the non-phenolic moieties in lignin (Call and Mücke, 1997; Leonowicz et al., 2001) and this has been widely studied in the pulp and paper industry in relation to delignification (Chandra and Ragauskas, 2005; Balakshin et al., 2001; Elegir et al., 2005; Rochefort et al., 2004). Among the known mediators, 2,2'-azinobis-(3-ethylbenzthiazoline)-6-sulfonate (ABTS) and 1-hydroxybenzotriazole (HBT) are the most commonly used (Ibarra et al., 2006; Leonowicz et al., 2001; Baiocco et al., 2003; Call and Mücke, 1997) and effective. Although, a number of studies have demonstrated the ability of laccase to modify technical lignins (Sena-Martins et al., 2008; Milstein et al., 1990, 1994; Hernández Fernaud et al., 2006; Lund and Ragauskas 2001; Popp et al., 1991), detailed characterization of the resulting chemical changes is still lacking. Here, we relate for the first time the enzymatic improvement of the dispersion properties of lignosulfonates to the chemical changes of the polymer. Detailed analysis was carried out by employing a number of different complementary techniques among them fluorescence monitoring, different nuclear magnetic resonance (NMR) techniques, Fourier transform infrared (FTIR) spectroscopy, size exclusion chromatography and chemical analysis.

\section{Methods}

\subsection{Materials}

Calcium lignosulfonate samples were provided by Borregaard (Sarpsborg, Norway). Among the enzymes used, NS51002 - Trametes villosa laccase (TvL) and NS 51003 - Myceliophthora thermophila laccase (MtL) were supplied by Novozymes (Bagsvaerd, Denmark). Trametes hirsuta laccase (ThL) and Bacillus spore laccase (BsL) were produced as previously described (Almansa et al., 2004; Held et al., 2005). All the other reagents used were of analytical grade purchased either from Sigma-Aldrich or Merck.

\subsection{Laccase activity assay}

The activity of laccase was determined spectrophotometrically by monitoring the oxidation of 2,2'-azinobis-(3-ethylbenzthiazoline)-6-sulfonate (ABTS) to its cation radical $\left(\varepsilon_{436}=29,300\right.$ $\mathrm{M}^{-1} \mathrm{~cm}^{-1}$ ) as substrate at $436 \mathrm{~nm}$ in $50 \mathrm{mM}$ sodium succinate buffer at $\mathrm{pH} 4.5$ and $30^{\circ} \mathrm{C}$ using quartz cuvette of path length $10 \mathrm{~mm}$ (Nugroho Prasetyo et al., 2009) and activity expressed in nano katals (nkat) corresponding to $1 \mathrm{nmol}$ of substrate converted per second.

\subsection{Polymerization of calcium lignosulfonates}

Calcium lignosulfonate samples were incubated with each of the above laccases separately. Briefly, $1 \mathrm{~g}$ of the calcium ligninosulfonate sample was dissolved in $50 \mathrm{ml}$ double distilled water in $250 \mathrm{ml}$ Erlenmeyer flasks and 1-hydroxybenzotriazole (HBT) or ABTS ( $1 \mathrm{mM}$ final concentration) added to the reaction mixture. The reaction was started by adding a 30 nkat $\mathrm{ml}^{-1}$ laccase activity as determined at the optimum $\mathrm{pH}$ value of the individual experiments. Samples were then incubated at $30^{\circ} \mathrm{C}$ while shaking at $150 \mathrm{rpm}$. Samples were withdrawn at regular intervals and fluorescence intensity measured instantly while the other part of the sample was immediately frozen by immersing in liquid nitrogen. The frozen samples were lyophilized using the Labconco Freeze Dry System / FreeZone 4 4.5 Liter Benchtop Model 77500 (Vienna, Austria). The freeze drier was operated at a temperature of $-48^{\circ} \mathrm{C}$ and at a vacuum pressure of $3 \times 10^{-4} \mathrm{mbar}$. These freeze dried samples were stored in the dark in sealed tubes at $4{ }^{\circ} \mathrm{C}$ until further analysis.

\subsection{Fluorescence intensity measurements}

During enzymatic polymerization fluorescence intensity was monitored (Ex $355 \mathrm{~nm} / \mathrm{Em} 400 \mathrm{~nm}$ ) at defined time intervals using TECAN Infinite M200 plate reader (Tecan Austria GmbH, Grödig, Austria). A lignin sample of $100 \mu \mathrm{l}$ was added to a solution of 2methoxyethanol (Thomson et al., 2005) and water $(2: 1 \mathrm{v} / \mathrm{v})$ and then thoroughly mixed before measuring.

\subsection{FTIR analysis}

FTIR spectra were obtained on a Perkin-Elmer Spectrum 2000 instrument by the attenuated total reflectance (ATR) technique. Spectra were recorded in the $4000-600 \mathrm{~cm}^{-1}$ range with 16 scans at a resolution of $4.0 \mathrm{~cm}^{-1}$ and an interval of $1.0 \mathrm{~cm}^{-1}$. Sulfonate groups were also detected by FTIR at 1145 and $647 \mathrm{~cm}^{-1}$.

\subsection{Size exclusion chromatography}

All lignosulfonates, being highly soluble in water, were analyzed using three TSK-gel columns (3000 PW, $4000 \mathrm{PW}$, $3000 \mathrm{PW}$ ) coupled in series with $0.1 \mathrm{M}$ sodium hydroxide as the eluant. Flow rate was $1 \mathrm{~mL} / \mathrm{min}$ and detection was done by UV at $280 \mathrm{~nm}$.

\subsection{NMR analysis}

Solution NMR spectra, including ${ }^{1} \mathrm{H}$ NMR, ${ }^{13} \mathrm{C}$ NMR and heteronuclear single quantum correlation (HSQC) 2D-NMR spectra were recorded on $40 \mathrm{mg}$ of lignosulfonate dissolved in $0.75 \mathrm{~mL}$ of DMSO- $d_{6}$ using a Bruker AVANCE $500 \mathrm{MHz}$ as previously described (Ibarra et al., 2006). A semiquantitative analysis of the HSQC crosssignal intensities was performed (Heikkinen et al., 2003; Zhang and Gellerstedt, 2007) including separate volume integrations and comparison in each of the regions of the spectrum, which contain cross-signals of chemically analogous carbon-proton pairs. Cross-polarization magic-angle spinning (CPMAS) ${ }^{13} \mathrm{C}$ NMR spectra of solid lignosulfonate samples were recorded for $9 \mathrm{~h}$ on a Bruker AVANCE DSX 300 using the standard pulse sequence, a time domain of $4 \mathrm{~K}$, a spectral width of $41,666 \mathrm{~Hz}$, a contact time of $2 \mathrm{~ms}$, and an interpulse delay of $4 \mathrm{~s}$. Signals were assigned by comparison with the literature (Bardet et al., 2006; Capanema et al., 2004; Lebo et al., 2008; Liitiä et al., 2003; Lundquist, 1981; Lutnaes et al., 2008; Martínez et al., 1999; Ralph et al., 1999; Ralph et al., 2004; Robert, 1992). 
2.8. Photon-correlation spectroscopy (PCS) and Zeta-potential measurements

The surface charge of the oxidized solutions was measured in terms of Zeta-potential in a Zetasizer Nano Series (Malvern Instruments Inc., Worcester, UK). This method measures how fast a particle moves in a liquid when an electrical field is applied i.e. its velocity. The aggregation behaviour of treated lignosulfonate particles in solution was therefore performed by determining its electrophoretic mobility. The size distribution of the oxidized samples was also measured by photon-correlation spectroscopy.

\subsection{Dispersion properties}

The Turbiscan MA 2000 from Sci-Tec Inc (Sandy Hook, USA) was used to assess the stability of suspensions (Mengual et al., 1999). Different enzyme-modified lignosulfonates are rated after their ability to stabilise a standard suspension. A similar procedure has been used to follow the sedimentation of suspensions (Balastre et al., 2002) and creaming of emulsions (Roland et al., 2003). The Turbiscan technology consists in measuring backscattering and transmission intensities versus the sample height in order to detect particle size change (coalescence, flocculation) and phase separation (sedimentation, creaming).

\subsection{0. $P y-G C / M S$}

The pyrolysis of the lignosulfonates (approximately $100 \mu \mathrm{g}$ ) was performed in duplicate with a model 2020 micro-furnace pyrolyzer (Frontier Laboratories Ltd., Yoriyama, Japan) directly connected to an Agilent $6890 \mathrm{GC} / \mathrm{MS}$ system equipped with a $30 \mathrm{~m} \times 0.25 \mathrm{~mm}$ i.d., $0.25 \mu \mathrm{m}$ HP 5MS fused silica capillary column. The detector consisted of an Agilent 5973 mass selective detector (EI at $70 \mathrm{eV}$ ). The pyrolysis was performed at $500^{\circ} \mathrm{C}$. The GC/MS conditions were as follows: the oven temperature was held at $50{ }^{\circ} \mathrm{C}$ for $1 \mathrm{~min}$ and then increased up to $100{ }^{\circ} \mathrm{C}$ at $30{ }^{\circ} \mathrm{C} / \mathrm{min}$, from 100 to $300{ }^{\circ} \mathrm{C}$ at $10^{\circ} \mathrm{C} / \mathrm{min}$ and isothermal at $300{ }^{\circ} \mathrm{C}$ for $10 \mathrm{~min}$. The carrier gas used was helium with a controlled flow of $1 \mathrm{ml} / \mathrm{min}$. The compounds were identified by comparing the mass spectra obtained with those of the Wiley and NIST computer libraries and that reported in the literature (Faix et al., 1990; Ralph and Hatfield, 1991). Sulfonate groups were also detected by Py-GC/MS.

\section{Results and discussion}

\subsection{Fluorescence intensity}

Fluorescence spectroscopy was used as a sensitive and simple analytical tool to optimize modification of calcium lignosulfonates with different laccases at different pHs. A similar trend was observed in fluorescence changes (decrease in fluorescence) when lignosulfonates were treated with laccases in the presence of either HBT or ABTS (Fig. 1a and b). TvL and ThL were effective in reducing fluorescence under acidic conditions ( $\mathrm{pH} 4.0$ and 4.5) while the BsL and the MTL were more effective at $\mathrm{pH}$ above 6 (Fig. 1a and b). The MTL performed slightly better than the BsL in the presence of both ABTS or HBT as mediators (Fig. 1a and b). Although the decrease in fluorescence measured for TvL and ThL treated lignin at $\mathrm{pH} 4.0$ and 4.5 was almost similar in the presence of ABTS or HBT, samples incubated with the latter performed slightly better. Similarly, at the same $\mathrm{pH}$ (4.5), the ThL reduced fluorescence was $2058 \mathrm{AU}$ in ABTS supplemented samples and 2828 AU in HBT incubated samples. Fluorescence is an intrinsic property of lignin attributed to conjugated carbonyl, biphenyl, phenylcoumarins and stilbene groups (Albinsson et al., 1999; Lundquist et al., 1978). Therefore, the observed decrease in fluorescence intensity in this study upon incubation with laccases indicated modification of these functional groups present in lignin. The destruction or modification of biphenyl groups, for example, has been shown to affect fluorescence intensity (Castellan et al., 1992). Here, the decrease in fluorescence was used as an indication of the extent of modification of the calcium lignosulfonates. The observed different modifications by the different enzymes maybe attributed to the different redox potential of the laccases. For example TvL and ThL are high redox potential laccases with redox potentials of approximately $+790 \mathrm{mV}$ (Rebrikov et al., 2006; Tadesse et al., 2008) while MTL and BsL are low redox potential laccases $(460 \mathrm{mV}$ and $455 \mathrm{mV}$, respectively) (Tadesse et al., 2008; Melo et al., 2007).

\subsection{Gel permeation chromatography}

The calcium lignosulfonate samples incubated with TvL and ThL underwent extensive polymerization. The $\mathrm{Mw}$ increased by $74 \%$ after $17 \mathrm{~h}$ of incubation with ThL and by $370 \%$ in TvL-treated samples (Table 1 ) supplemented with $0.5 \mathrm{mM}$ HBT. Polymerization as a central feature during laccase oxidation of lignin moieties has also been reported by previous authors (Ishihara and Miyazaki, 1972; Hüttermann et al., 1980; Elegir et al., 2007). As indicated earlier by Karhunen et al. $1990 \mathrm{a}$ and b, the radicals generated by laccases underwent resonance stabilisation forming different mesomeric forms that coupled in many possibilities forming inter-unit linkages which include $\beta-0-4, \beta-5,5-5, \beta-\beta, 5-0-4$ resulting in polymers of different sizes. In this study, the increase in Mw was accompanied by a decrease in phenolic groups and carboxylic groups. Several authors have observed a similar decrease in phenolic groups (Shleev et al., 2006, Grönqvist et al., 2005, Rittstieg et al., 2002; Buchert et al., 2002). This indicates that the laccase-HBT oxidized phenolic substituents and generated phenoxy radicals which underwent coupling reactions leading to the observed polymerization. The content of carboxylic groups in lignin decreased by $2 \%$ for ThL and by $2.4 \%$ for TvL after $17 \mathrm{~h}$ of incubation, respectively (Table 1).

The effect of increasing incubation time and doubling HBT concentration was investigated in subsequent experiments (Table 2). Increasing incubation time to $83 \mathrm{~h}$ and HBT concentration to $1 \mathrm{mM}$ (final concentration) resulted in $107 \%$ and $572 \%$ increase in Mw of ThL and TvL incubated calcium lignosulfonate samples, respectively. The changes in $\mathrm{Mw}$ are clearly visible in size exclusion chromatography (Fig. $2 \mathrm{ThL}, \mathrm{TvL}$ ). The Mw of TvL incubated samples clearly changed resulting in a narrower Mw band, comparing chromatograms of samples incubated for $0 \mathrm{~h}$ and $83 \mathrm{~h}$. Although there was a clear modification of lignosulfonates in ThL samples, the modifications are different from those obtained in TvL samples. Previous researchers have also reported polymerization of lignosulfonates by laccases (Leonowicz et al., 1985; Hatakka et al., 1996; Bae and Kim, 1996), although the use of ABTS as a laccase mediator was repeatedly resulted in depolymerizaion of lignin (Hernández Fernaud et al., 2006; Bourbonnais et al., 1995) and was even shown to be incorporated in polymerization products (Rittstieg et al., 2002).

An increase in incubation time and HBT concentration lead only to a marginal further decrease in phenolic and carboxylic groups. The phenolic content decreased from $1.4 \mathrm{mmol} \mathrm{g}^{-1}$ in the untreated lignosulfonate sample to $0.85 \mathrm{mmol} \mathrm{g}^{-1}$ after $83 \mathrm{~h}$ incubation with ThL and to $0.45 \mathrm{mmol} \mathrm{g}^{-1}$ after incubation with TvL (Table 2). There was a small decrease in the organic sulfur content and a slight increase in inorganic sulfur content in both samples upon enzyme treatment (Table 2). This loss of sulfonic acid groups might be responsible for the in the Zeta-potential. This parameter increased from 0.65 to $2.4 \mathrm{mV}$ in ThL-treated samples and from 0.6 


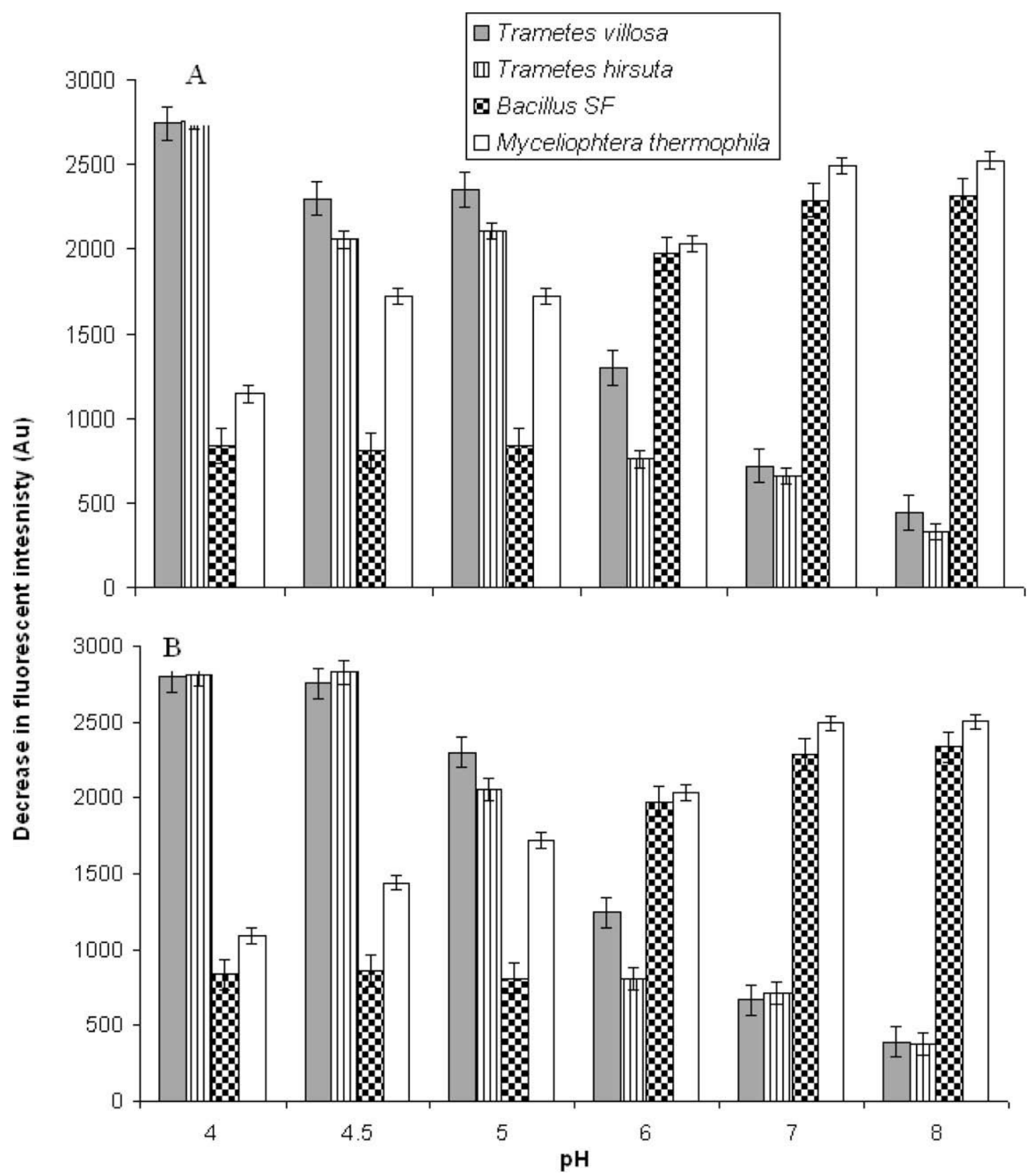

Fig. 1. Fluorescence decrease of lignosulfonate after incubation with different laccases in the presence of HBT (A) and ABTS (B) at different pHs after 83 h of incubation. Data is an average of 3 independent replicates \pm standard deviation.

Table 1

Changes in molecular weight (Mw) and functional group content after treatment of lignosulfonates with different laccases in the presence of HBT.

\begin{tabular}{ccccccl}
\hline Laccase & $\begin{array}{l}\text { Time } \\
(\mathrm{h})\end{array}$ & $\mathrm{Mw}$ & $\mathrm{Mn}$ & $\mathrm{Pdi}$ & $\begin{array}{l}\text { Ar-OH } \\
(\%)\end{array}$ & $\begin{array}{l}\mathrm{COOH} \\
(\%)\end{array}$ \\
\hline $\begin{array}{c}\text { Trametes } \\
\text { hirsuta }\end{array}$ & 0 & 30800 & 1900 & 16.21 & 1.9 & 7.5 \\
& 0.5 & 29700 & 1900 & 15.63 & - & - \\
& 17 & 53800 & 4300 & 12.51 & 1.4 & 5.6 \\
Trametes & & & & & & \\
villosa & 0 & 29400 & 1800 & 16.33 & 1.9 & 7.5 \\
& 0.5 & 40400 & 2950 & 13.69 & 1.5 & 5.6 \\
& 17 & 140100 & 8250 & 16.98 & 1.0 & 5.1 \\
\hline
\end{tabular}

Mn-number average molecular weight; Pdi-polydispersity.

to $2.2 \mathrm{mV}$ in TvL-treated samples. The particle size [Z-average (d.nm)] increased from 369.4 to 942.8 in ThL and 311.0 to 421.2 in TvL samples indicating aggregation of particles. Unlike TvL-treated samples for $83 \mathrm{~h}$, ThL samples became partly insoluble.

\subsection{FTIR analysis}

FTIR spectroscopy at mid-infrared region (4000-600 $\left.\mathrm{cm}^{-1}\right)$ was applied to monitor structural changes occurring during incubation of the calcium lignosulfonate with the ThL and TvL (Fig. $2 \mathrm{ThL}$ and TvL). In the FTIR spectra bands at $1595 \mathrm{~cm}^{-1}$ and $1520 \mathrm{~cm}^{-1}$ suggest aromatic ring vibrations and at $1033 \mathrm{~cm}^{-1}$, aromatic $\mathrm{C}-\mathrm{H}$ inplane deformation (Fig. $2 \mathrm{ThL}$ and TvL). Sulfonate groups are shown by bands at around $1145 \mathrm{~cm}^{-1}$ (asymmetric and symmetric $-\mathrm{SO}_{2}-$ vibrations) and one band at around $647 \mathrm{~cm}^{-1}$ (from S-O structure). Further the stretching vibrations of alcoholic and phenolic $\mathrm{OH}$ groups involved in hydrogen bonds were detected between $3500-3200 \mathrm{~cm}^{-1}$. Further analysis of the region between 1645 
Table 2

Changes during incubation of Trametes hirsuta and Trametes villosa laccase-HBT systems with lignosulfonates.

\begin{tabular}{|c|c|c|c|c|c|c|c|}
\hline Laccase & Time (h) & Mw & Mn & Inorganic S (\%) & Organic S (\%) & $\mathrm{Ar}-\mathrm{OH}(\%)$ & $\mathrm{COOH}(\%)$ \\
\hline \multicolumn{8}{|c|}{ T. hirsuta } \\
\hline & 0 & 28400 & 2650 & 0.8 & 5.4 & 1.8 & 7.4 \\
\hline & 17 & 43100 & 3800 & 0.8 & 5.0 & 1.4 & 6.1 \\
\hline & 83 & 58800 & 5250 & 1.0 & 5.1 & 1.1 & 5.4 \\
\hline \multicolumn{8}{|l|}{ T. villosa } \\
\hline & 0 & 28400 & 2650 & 0.9 & 5.2 & 1.9 & 7.4 \\
\hline & 17 & 142400 & 9200 & 1.0 & 4.9 & 1.1 & 5.2 \\
\hline & 83 & 191100 & 10500 & 1.0 & 5.1 & 1.0 & 5.0 \\
\hline
\end{tabular}
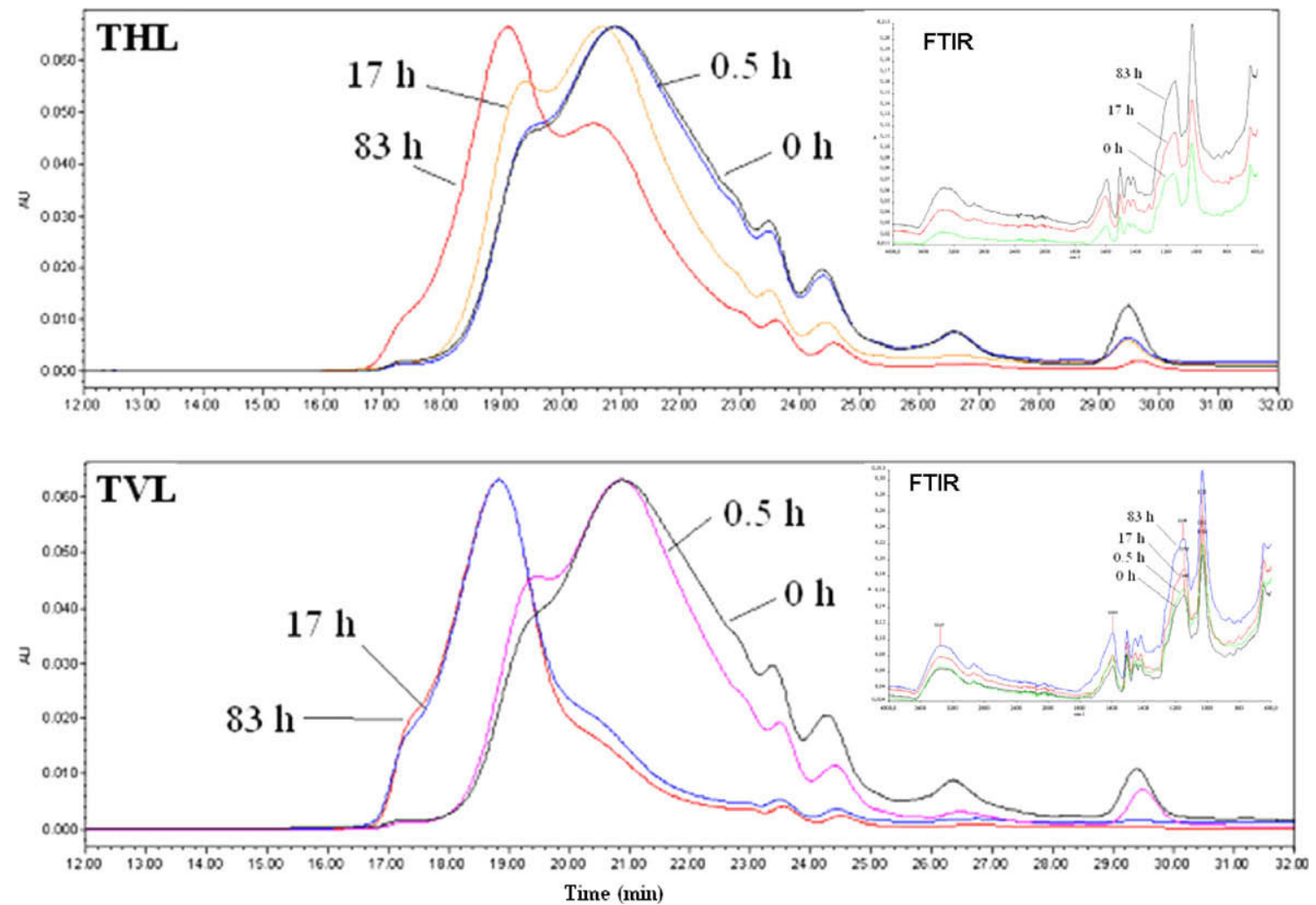

Fig. 2. Polymerization of lignosulfonates by Trametes hirsuta laccase (THL) and Trametes villosa laccase (TVL) in the presence of HBT after $0,0.5$, 17 and $83 \mathrm{~h}$ of incubation as monitored by size exclusion chromatography. Inserts show results of FTIR analysis of the lignosulfonates.

and $1760 \mathrm{~cm}^{-1}$, reveals no noticeable changes in carbonyl or carboxylic acid group present or generated by the treatments in the structures. As a general conclusion, according to the FTIR data, no substantial changes were introduced in the calcium lignosulfonates samples during incubation with both TvL and ThL.

\subsection{Dispersion properties}

Indeed, the dispersant properties of the enzyme treated lignosulfonate were significantly improved as shown in Fig. 3. A low value of delta backscattering indicates a more stable suspension. The increased $\mathrm{Mw}$ and reactivity of the enzyme treated lignosulfonates could have enhanced its miscibility. Previously, prepared lignosulfonates by phenolation were shown to increase dispersibility by over $30 \%$ for gypsum paste than the commercial lignosulfonate (Matsushita and Yasuda, 2005). They attributed the improvement in dispersion properties to increased $\mathrm{Mw}$ and sulfur contents of the preparations. This is inline with the observation in this study where an increase in $\mathrm{Mw}$ and reactivity were noted and a very marginal loss of sulfur. The fact that laccase did not remove sulfur is very encouraging because sulfonate groups are important for imparting solubility properties to lignins.

For example, sulfonation leads to water-soluble anionic polymers and high-dispersibility gypsum paste (Matsushita et al., 2008; Li et al., 2009). The dispersing efficiency increased as the surface tension decreased, suggesting that the fluidity of the gypsum paste increased with the polymer adsorption on the gypsum particle surface (Matsushita et al., 2008). This phenomenon may also be attributed to the observed increase in dispersion properties in this study.

\subsection{NMR analysis of enzymatically-modified lignosulfonates}

In contrast to FTIR data, the HSQC NMR analysis (Fig. 4) showed decreases in the intensities of cross-signals in the three main regions of the lignosulfonate spectrum, corresponding to aromatic 


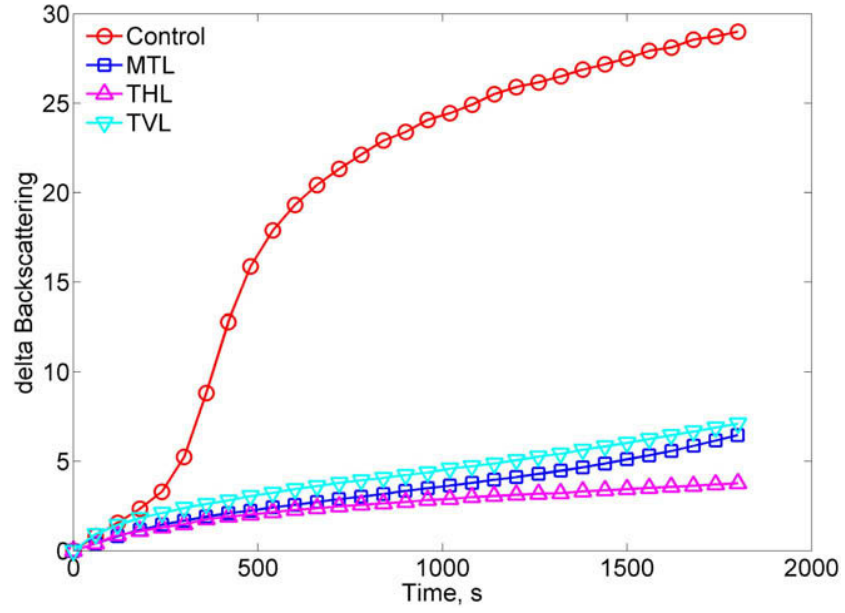

Fig. 3. Dispersibility of lignosulfonates polymerized with laccases from Myceliopthera thermophilia, Trametes hirsuta and Trametes villosa (MTL, THL and TVL) in the presence of HBT, based on multiple light scattering (BS - Backscattered and T transmitted light compared to a control and to chemically modified lignosulfonate after $17 \mathrm{~h}$ incubation.

$\left(\delta_{\mathrm{H}} / \delta_{\mathrm{C}} 5.5-8 / 105-140 \mathrm{ppm}\right)$, aliphatic oxygenated $\left(\delta_{\mathrm{H}} / \delta_{\mathrm{C}} 2.5-5.5 /\right.$ $50-105 \mathrm{ppm})$ and aliphatic non-oxygenated $\left(\delta_{\mathrm{H}} / \delta_{\mathrm{C}} \quad 0-3 / 0-\right.$ $50 \mathrm{ppm}){ }^{1} \mathrm{H}-{ }^{13} \mathrm{C}$ correlations, albeit with very different decrease intensities in each of them. The HSQC spectra were obtained from the same amount of sample ( $40 \mathrm{mg}$ in $0.75 \mathrm{~mL}$ of $\mathrm{DMSOd}_{6}$ ) and normalized to the residual DMSO cross-signal $\left(\delta_{\mathrm{H}} / \delta_{\mathrm{C}} 2.5 / 40 \mathrm{ppm}\right)$. The above decreases were observed in both the samples treated with TvL (Fig. 4a and b) and ThL (Fig. 4c and d).

After $83 \mathrm{~h}$ incubation the aromatic cross-signals found in the HSQC spectrum of the control $(0-\mathrm{h})$ lignosulfonate, which corresponded to $\mathrm{H}_{2}-\mathrm{C}_{2}, \mathrm{H}_{5}-\mathrm{C}_{5}$ and $\mathrm{H}_{6}-\mathrm{C}_{6}$ correlations (with $\delta_{\mathrm{H}} / \delta_{\mathrm{C}}$
6.91/114.7, 6.65/114.9 and 6.75/122.9 ppm, respectively) completely disappeared in the TvL-treated samples. On the other hand, they were still partially visible in the ThL-treated samples although with very strongly reduced intensities. In addition, the methoxyl cross-signal (with $\delta_{\mathrm{H}} / \delta_{\mathrm{C}} 3.72 / 56.2 \mathrm{ppm}$ ) significantly decreased in both the TvL and ThL-treated samples, together with those of the most abundant $\beta-0-4^{\prime}$ linked $\alpha$-sulfonated side-chains including $\mathrm{H}_{\beta}-\mathrm{C}_{\beta}$ correlation (with $\delta_{\mathrm{H}} / \delta_{\mathrm{C}} 4.93 / 80.1 \mathrm{ppm}$ ), while polysaccharide and other oxygenated aliphatic cross-signals remained practically unaffected by the laccase-mediator treatment. Finally, only a few and small cross-signals of non-oxygenated aliphatic correlations were observed in the lignosulfonate spectra including that from the methyl of the acetate buffer used for the enzymatic treatment (with $\delta_{\mathrm{H}} / \delta_{\mathrm{C}} 1.1 / 19 \mathrm{ppm}$ ).

The disappearance of the aromatic ${ }^{1} \mathrm{H}-{ }^{13} \mathrm{C}$ correlation signals in the TvL treated lignosulfonate after $83 \mathrm{~h}$ of incubation, as shown by HSQC 2D-NMR, was initially unexpected. Therefore this sample and its (0-time) control were further analyzed by ${ }^{1} \mathrm{H}$ NMR, and by both liquid and solid state ${ }^{13} \mathrm{C}$ NMR (Fig. 5). The latter was used to solve eventual solubility problems due to enzymatic polymerization, although no DMSO insoluble material was observed in the NMR tubes.

The loss of aromatic cross-signals in the HSQC spectra obtained after the enzymatic treatment (Fig. 5a) was due to deprotonation of the lignin benzenic rings, as revealed by the 1D-NMR spectra. In this way, no aromatic proton signals were found in the $1 \mathrm{H}$ NMR spectrum of the lignosulfonate treated with TvL for $83 \mathrm{~h}$ (Fig. $5 \mathrm{~b}$ ) while strong signals of aromatic carbons appeared in the ${ }^{13} \mathrm{C}$ NMR spectra obtained either in solution (Fig. 5c) or in the solid state using the CPMAS technique (Fig. $5 \mathrm{~d}$ ). This suggests formation of new ether and C-C aryl-aryl or aryl-alkyl linkages as a result of the enzymatic attack on the lignosulfonate aromatic nuclei causing the strong polymerization observed by SEC. After initial condensation reactions between the phenoxy radicals formed by the action of the enzyme on the phenolic units present in the initial lignosul-

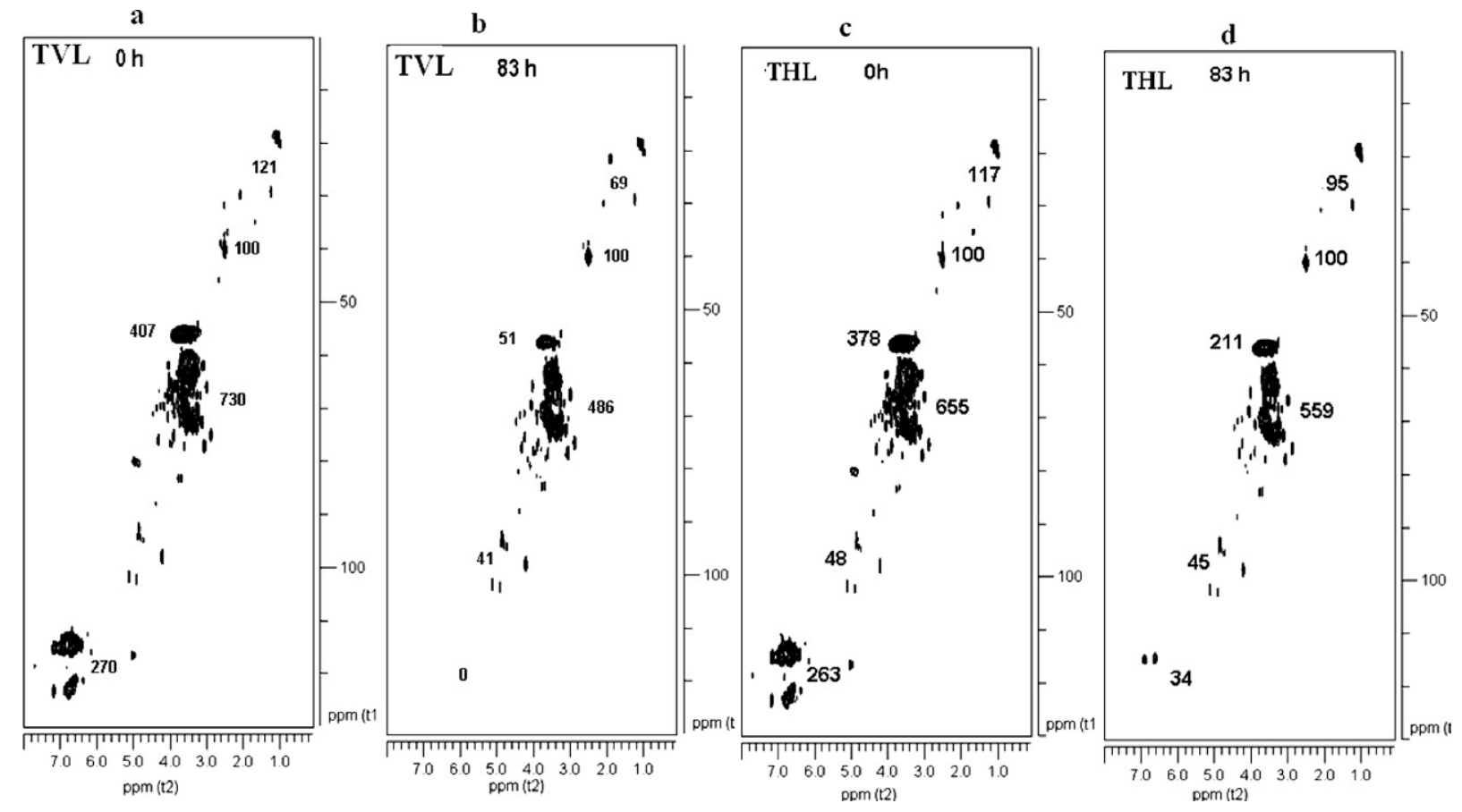

Fig. 4. HSQC 2D-NMR analysis of lignosulfonate modification by Trametes hirsuta laccase (THL) (right) and Trametes villosa laccase (TVL) (left) in the presence of HBT after $0 \mathrm{~h}$ (a and c, respectively) and $83 \mathrm{~h}$ (b and d, respectively) of incubation. The integrals of the main groups of ${ }^{1} \mathrm{H}-{ }^{13} \mathrm{C}$ correlation signals (from bottom to top: aromatic signals, anomeric polysaccharide signals, different oxygenated aliphatic signals, methoxyl signal, and non-oxygenated aliphatic signals) are indicated, referred to the residual DMSO signal (as 100\%). 


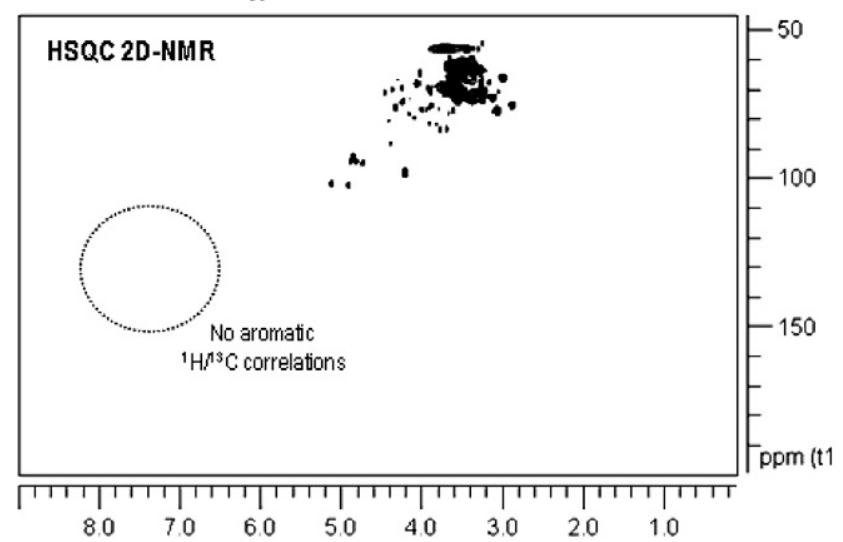

b

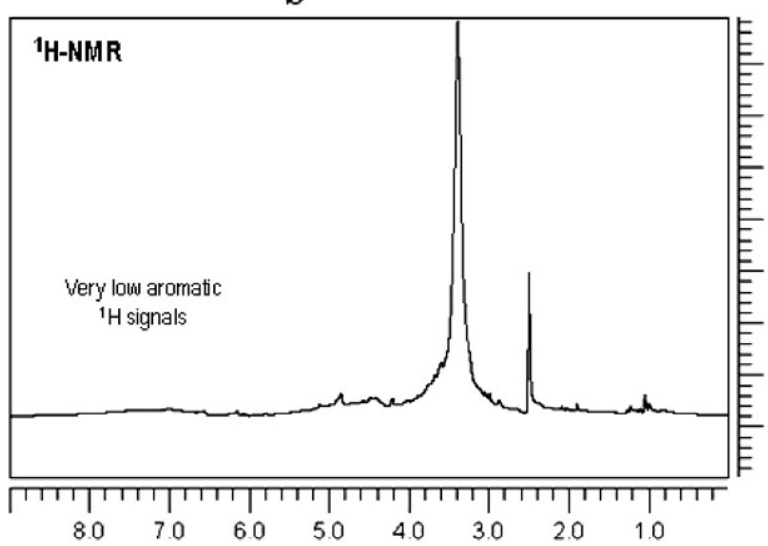

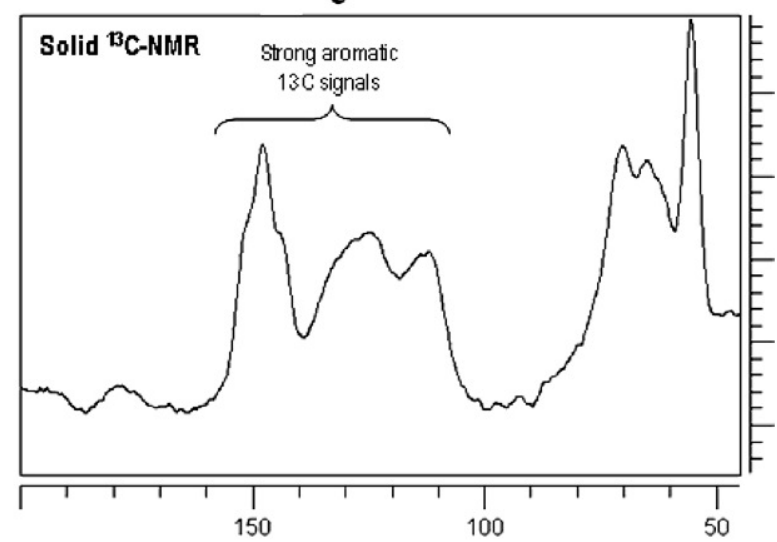

d

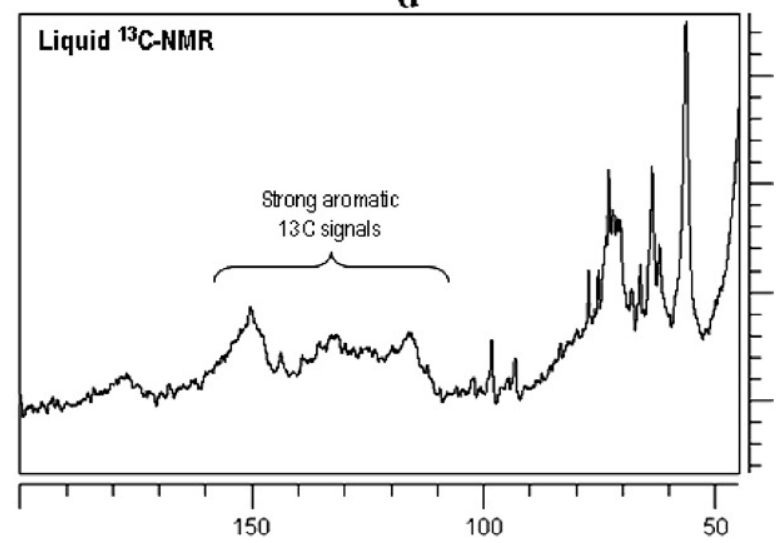

Fig. 5. Comparison of aromatic signals in (a) HSQC 2D-NMR spectrum $\left({ }^{1} \mathrm{H}-{ }^{13} \mathrm{C}\right.$ correlation), (b) ${ }^{1} \mathrm{H}$ NMR spectrum, (c) ${ }^{13} \mathrm{C}$ NMR spectrum, and (d) CPMAS ${ }^{13} \mathrm{C}$ NMR spectrum of spruce lignosulfonate after $83 \mathrm{~h}$ incubation with Trametes villosa laccase (TVL)-HBT system.

THL
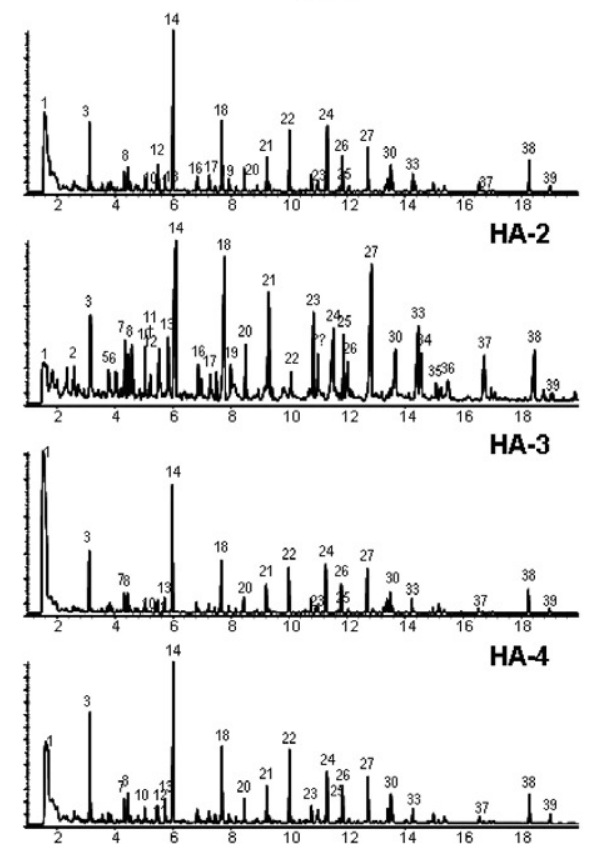

TVL

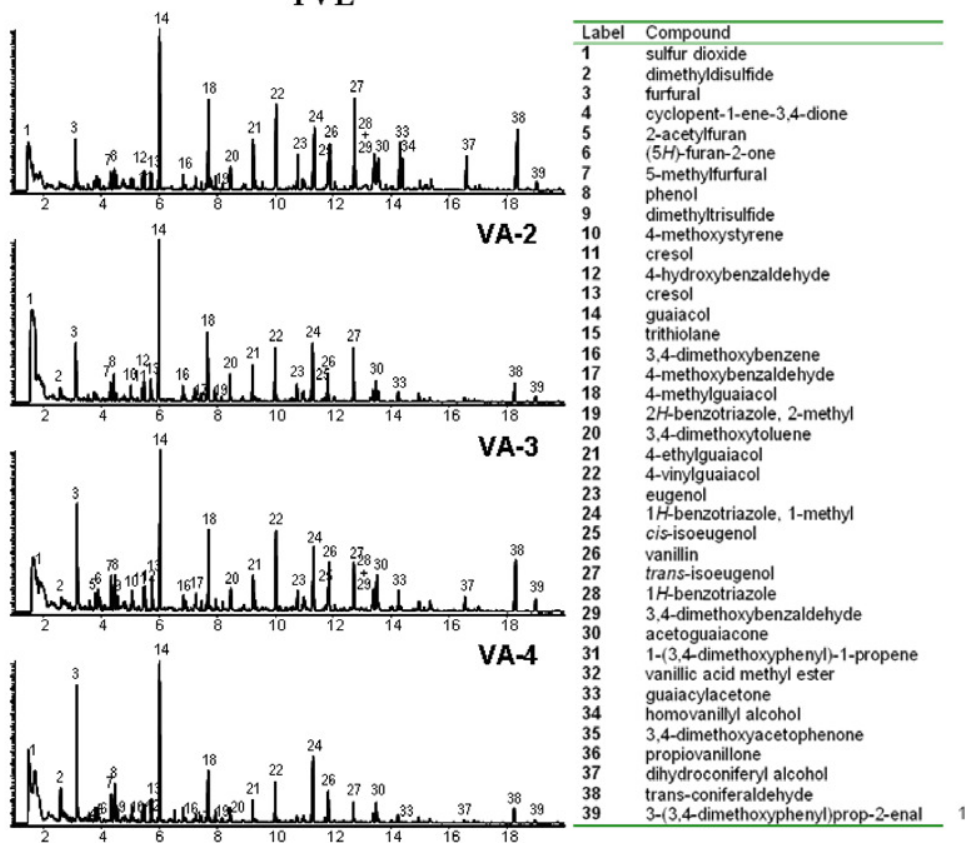

Fig. 6. Py-GC/MS of calcium lignosulfonate during incubation with Trametes hirsuta laccase (THL) and Trametes villosa laccase (TVL) in the presence of HBT.

fonate sample, the high redox-potential laccase-HBT system most probably cause additional oxidative attack on the non-phenolic lig- nin nuclei resulting in additional deprotonation and condensation reactions. 


\subsection{Py-GC/MS of enzymatically-modified lignosulfonates}

The chemical composition of the lignosulfonates was analyzed by Py-GC/MS (Fig. 6). The compounds released arise mainly from lignin moieties with minor amounts of carbohydrates and sulfur compounds being present. Among the lignin derived compounds, only guaiacyl derivatives were detected, as corresponds to a lignosulfonate from softwood. The most interesting observation obtained from Py-GC/MS pyrograms was the decrease in the intensity of the lignin peaks (4-methylguaiacol, 4-ethylguaiacol, guaiacylacetone, 4-vinylguaiacol, homovanillylalcohol, eugenol, cis- and trans-isoeugenol, dihyroconiferyl alcohol and trans-coniferaldehyde), in both TvL and ThL-treated samples (Fig. 6). The decrease in the different lignin moieties was accompanied by a concomitant increase in sulfur dioxide and dimethyldisulfide. Lignin markers were very much present as detected by Py-GC/MS in all the samples during the whole incubation period despite a slight decrease at longer incubation periods (Fig. 6).

The FTIR and ${ }^{13} \mathrm{C}$ NMR spectra together with Py-GC/MS chromatograms suggesting no substantial structural changes in the calcium lignosulfonate aromatic structure are a good indication of the ability of TvL and ThL to limit their effect to effective cross-linking, without degrading the lignin backbone. These data are in line with reports by Martinnen et al. (2008) who also did not observe substantial differences in the aromatic signals after laccase treatment of lignin. The seemingly contradictory aromatic data by HSQC 2DNMR, showing the disappearance of the aromatic cross-signals, may be due to the strong polymerization produced by the laccase-HBT treatment. This resulted in new carbon-carbon and carbon-oxygen linkages leading to condensation and/or modification reactions in such a way that most lignin aromatic carbons were unprotonated, the remaining ones being below the HSQC detection level. Some problems associated with 2D-NMR spectroscopy are related to the short $T_{1}$ and $T_{2}$ relaxation times (Garver et al., 1996 and Zhang and Gellerstedt, 2007 suggested the degree of polymerization as one of the factors affecting short $T_{2}$ values in HSQC NMR. Our observation seems to also vindicate earlier comments by Capanema et al. (2004) who emphasized a need for caution when analyzing 2D-NMR spectra of lignin data that must be complemented with $1 \mathrm{D}\left({ }^{1} \mathrm{H}\right.$ and ${ }^{13} \mathrm{C}$ NMR $)$ spectra.

\section{Conclusions}

Size exclusion chromatography analysis of ThL-HBT and TvLHBT treated lignosulfonate resulted in extensive polymerization leading to $107 \%$ and $572 \%$ increase in Mw from 28400 Da, respectively. New ether and C-C aryl-aryl or aryl-alkyl linkages were detected as causing the strong polymerization as confirmed by FTIR, ${ }^{13} \mathrm{C}$ NMR spectra and Py-GC/MS chromatograms. Nevertheless, the treatment did not affect the lignin backbone, a good indication of the ability of TvL and ThL-HBT systems to limit their effect to the functional groups only. As a result, the dispersant properties of the enzyme treated lignosulfonate increased significantly.

\section{Acknowledgements}

Financial support from the BIORENEW EU-project (NMP2-CT2006-26456), Austrian Academic Exchange Programme (ÖEAD) and the Spanish projects BIO2007-28720-E, BIO2008-01533, and AGL2008-00709 is acknowledged.

\section{References}

Albinsson, B., Li, S., Lundquist, K., Stomberg, R., 1999. The origin of lignin fluorescence. J. Mol. Struct. 508, 19-27.
Alexy, P., Košíková, B., Podstránska, G., 2000. The effect of blending lignin with polyethylene and polypropylene on physical properties. Polymer 41 (13), 49014908.

Almansa, E., Kandelbauer, A., Pereira, L., Cavaco, P., Guebitz, G.M., 2004. Influence of structure on dye degradation with laccase mediator systems. Biocatal. Biotransformation 22, 315-324.

Askvik, K.M., Hetlesæther, S., Sjoblom, J., Stenius, P., 2001. Properties of the lignosulfonate-surfactant complex phase. Colloids Surf., A 182, 175-189.

Bae, H.J., Kim, Y.S., 1996. Degradation of lignosulfonates by simultaneous action of laccase and Mn-peroxidase. In: Biotechnology in the Pulp and Paper Industry. ACS, Vienna.

Baiocco, P., Barreca, A.M., Fabbrini, M., Galli, C., Gentili, P., 2003. Promoting laccase activity towards non-phenolic substrates: a mechanistic investigation with some laccase-mediator systems. Org. Biomol. Chem. 1, 191-197.

Balakshin, M., Capanema, E., Chen, C.L., Gratzl, J., Kirkman, A., Gracz, H., 2001. Biobleaching of pulp with dioxygen in the laccase-mediator system-reaction mechanism for degradation of residual lignin. J. Mol. Catal. B. Enzym. 13, 1-16.

Balastre, M., Argillier, J.F., Allain, C., Foissy, A., 2002. Role of polyelectrolyte dispersant in the settling behaviour of barium sulphate suspension. Colloids Surf., A 211 (2-3), 145-156.

Bardet, M., Lundquist, K., Parkas, J., Robert, D., von Unge, S., 2006. C-13 assignments of the carbon atoms in the aromatic rings of lignin model compounds of the arylglycerol beta-aryl ether type. Magn. Reson. Chem. 44, 976-979.

Boerjan, W., Ralph, J., Baucher, M., 2003. Lignin biosynthesis. Annu. Rev. Plant Biol. 54, 519-546.

Bourbonnais, R., Paice, M.G., Reid, I.D., Lanthler, P., Yaguchi, M., 1995. Lignin oxidation by laccase isozymes from Trametes versicolor and role of the mediator 2,29-azinobis(3-ethylbenzthiazoline-6-sulfonate) in kraft lignin depolymerization. Appl. Environ. Microbial. 61 (5), 1876-1880.

Buchert, J., Mustranta, A., Tamminen, T., Spetz, P., Holmbom, B., 2002. Modification of spruce lignans with Trametes hirsuta laccase. Holzforschung 56, 579-584.

Call, H.P., Mücke, I., 1997. History, overview and applications of mediated lignolytic systems, especially laccase mediator-systems (lignozym-process). J. Biotechnol. 53, 163-202.

Capanema, E.A., Balakshin, M.Y., Kadla, J.F., 2004. A comprehensive approach for quantitative lignin characterization by NMR spectroscopy. J. Agric. Food Chem. $52,1850-1860$

Castellan, A., Nourmamode, A., Noutary, C., Belin, C., de Violet, P., 1992. Photoyellowing of milled wood lignin and peroxide-bleached milled mood lignin in solid 2-hydroxypropylcellulose films after sodium borohydride reduction and catalytic hydrogenation in solution: a fluorescence spectroscopic. J. Wood Chem. Technol. 12 (1), 19-33.

Cazacu, G., Mihaies, M., Pascu, C., Profire, L., Kowarskik, A.L., Vasile, C., 2004. Polyolefin/lignosulfonate blends. Macromol. Mater. Eng. 289, 880-889.

Chandra, R.P., Ragauskas, A.J., 2005. Modification of high-lignin kraft pulps with laccase. Part 2. xylanase-enhanced strength benefits. Biotechnol. Prog. 21, 1302-1306.

Dence, C.W., Lin, S.Y., 1992. Methods in lignin chemistry. In: Springer Series in Wood Science, pp. 1-14.

Ekeberg, D., Gretland, K.S., Gustafsson, J., Bråtenc, S.M., Fredheimc, G.E., 2006. Characterisation of lignosulfonates and kraft lignin by hydrophobic interaction chromatography. Anal. Chim. Acta 565, 121-128.

El Mansouri, N.-E.E., Salvado, J., 2006. Structural characterization of technical lignins for the production of adhesives: application to lignosulfonate, kraft, sodaanthraquinone, organosolv and ethanol process lignins. J. Ind. Crops Prod. 24, 8-16.

Elegir, G., Daina, S., Bestetti, G., Orlandi, M., 2005. Laccase mediator system: oxidation of recalcitrant model structures present in residual kraft lignin. Enzyme Microb. Technol. 37, 340-346.

Elegir, G., Bussini, D., Antonsson, S., Lindström, M.E., Zoia, L., 2007. Laccase-initiated cross-linking of lignocellulose fibres using a ultra-filtered lignin isolated from kraft black liquor. Appl. Microbiol. Biotechnol. 77, 809-817.

Faix, O., Meier, D., Fortmann, I., 1990. Thermal degradation products of wood. A collection of electron of electron-impact (EI) mass spectra of monomeric lignin derived products. Holz Roh-Werkst. 48, 351-354.

Flory, P.J., 1953. Principles of Polymer Chemistry. Cornell University Press, Ithaca.

Gargulak, J.D., Lebo, S.E., 2000. Commercial use of lignin-based materials. In: Lignin: Historical, Biological, and Material Prospectives. American Chemical Society, Washington, DC, pp. 304-320.

Garver, T.M., Maa, K.J., Marat, K., 1996. Conformational analysis and 2D NMR assignment strategies for lignin model compounds. The structure of acetoguaiacyl-dehydro-diisoeugenol methyl ether. Can. J. Chem. 74, 173-184.

Glasser, W.G., Sarkanen, S., 1989. Lignin: properties and materials. In: ACS Symposium-Series.

Gosselink, R.J.A., de Jong, E., Guran, B., Abächerli, A., 2004. Co-ordination network for lignin-standardisation, production and applications adapted to market requirements (EUROLIGNIN). Ind. Crops Prod. 20, 121-129.

Grönqvist, S., Viikari, L., Niku-Paavola, M.-L., Orlandi, M., Canevali, C., Buchert, J., 2005. Oxidation of milled wood lignin with laccase, tyrosinase and horseradish peroxidase. App. Microbiol. Biotechnol. 67 (4), 489-494.

Hatakka, A., Mettälä, A., Toikka, M., Hortling, B., Brunow, G., 1996. Modification of lignin by laccase and manganese peroxidase. In: Srebotnik, E., Messner, K. (Eds.), Biotechnology in the Pulp and Paper Industry: Advances in Applied and Fundamental Research (Proc. of the 6th International Conference on Biotechnology in the Pulp and Paper Industry). Facultas-Universitätsverlag, Vienna, Austria, pp. 333-338. 
Heikkinen, S., Toikka, M.M., Karhunen, P.T., Kilpeläinen, I.A., 2003. Quantitative 2D HSQC (Q-HSQC) via suppression of J-dependence of polarization transfer in NMR spectroscopy: application to wood lignin. J. Am. Chem. Soc. 125, 43624367.

Held, C., Kandelbauer, A., Schroeder, M., Cavaco-Paulo, A., Guebitz, G.M., 2005 Biotransformation of phenolics with laccase containing bacterial spores. Environ. Chem. Lett. 3 (2), 74-77.

Hernández Fernaud, J.R., Carnicero, A., Perestelo, F., Hernandez Cutuli, M., Arias, E. Falcón, M.A., 2006. Upgrading of an industrial lignin by using laccase produced by Fusarium proliferatum and different laccase-mediator systems. Enzyme Microb. Technol. 38, 40-48.

Hüttermann, A., Herche, C., Haars, A., 1980. Polymerization of water-insoluble lignins by Fomes annosus. Holzforschung 34, 64-66.

Hüttermann, A., Mai, C., Kharazipour, A., 2001. Modification of lignin for the production of new compound materials. Appl. Microbiol. Biotechnol. 55, 387 394.

Ibarra, D., Camarero, S., Romero, J., Martinez, M.J., Martinez, A.T., 2006. Integrating laccase-mediator treatment into an industrial-type sequence for totally chlorine-free bleaching of eucalypt kraft pulp. J. Chem. Technol. Biotechnol. 81, 1159-1165.

Ishihara, T., Miyazaki, M., 1972. Oxidation of milled wood lignin by fungal laccase. Mokuzai Gakkaishi 18 (8), 415-419.

Karhunen, E., Kantelinen, A., Niku-Paavola, M., 1990a. Mn-dependent peroxidase from the lignin-degrading white rot fungus Phlebia radiata. Arch. Biochem. Biophys. 279 (1), 25-31.

Karhunen, E., Niku-Paavola, M., Viikari, L., Haltia, T., Meer, R.V., Duine, J., 1990b. A novel combination of prosthetic groups in a fungal laccase, PQQ and two copper atoms. Febs Lett. 267 (1), 6-8.

Kosbar, L.L., Gelorme, J., Japp, R.M., Fotorny, W.T., 2001. Introducing biobased materials into the electronics industry. J. Ind. Ecol. 4, 93-98.

Lebo, S.E., Braaten, S.M., Fredheim, G.E., Lutnaes, B.F., Lauten, R.A., Myrvold, B.O. McNally, T.J., 2008. Recent advances in the characterization of lignosulfonates. In: Hu, T. (Ed.), Characterization of Lignocellulosic Materials. Blackwell Pub. New York, pp. 189-205.

Leonowicz, A., Szklarz, G., Wojta-Wasilewska, M., 1985. The effect of fungal laccase on fractionated lignosulfonates (Peritan Na). Phytochemistry 24 (3), 393-396.

Leonowicz, A., Cho, N.-S., Luterek, J., Wilkolazka, A., Wojtas, M., Matuszewska, A. Hofrichter, M., Wesenber, D., Rogalski, J., 2001. Fungal laccase: properties and activity on lignin. J. Basic Microbiol. 41 (3-4), 185-227.

Li, Y., Mlynar, J., Sarkanen, S., 1997. The first 85\% kraft lignin-based thermoplastics. J. Polym. Sci. Pt B-Polym. Phys. 35 (12), 1899-1910.

Li, Z., Pang, Y., Lou, H., Qiu, X., 2009. Influence of lignosulfonates on the properties of dimethomorph water-dispersible granules. BioResources 4 (2), 589-601.

Liitiä, T.M., Maunu, S.L., Hortling, B., Toikka, M., Kilpeläinen, I., 2003. Analysis of technical lignins by two- and three-dimensional NMR spectroscopy. J. Agric. Food Chem. 51, 2136-2143.

Lora, J.H., Glasser, W.G., 2002. Recent industrial applications of lignins; a sustainable alternative to non-renewable materials. J. Polym. Environ. 10, 39-

Lund, M., Ragauskas, A.J., 2001. Enzymatic modification of kraft lignin through oxidative coupling with water-soluble phenols. Appl. Microbiol. Biotechnol. 55 699-703.

Lundquist, K., 1981. NMR studies of lignins. 5. Investigation of non-derivatized spruce and birch lignin by ${ }^{1 \mathrm{H}} \mathrm{NMR}$ spectroscopy. Acta Chem. Scand. B 35, $497-$ 501.

Lundquist, K., Josefsson, B., Nyquist, G., 1978. Analysis of lignin products by fluorescence spectroscopy. Holzforschung 32, 27-32.

Lutnaes, B.F., Myrvold, B.O., Lauten, R.A., Endeshaw, M.M., 2008. ${ }^{1} \mathrm{H}$ and ${ }^{13} \mathrm{C}$ NMR data of benzylsulfonic acids-model compounds for lignosulfonate. Magn. Reson. Chem. 46, 299-305.

Martínez, A.T., Almendros, G., González-Vila, F.J., Fründ, R., 1999. Solid-state spectroscopic analysis of lignins from several Austral hardwoods. Solid State NMR 15, 41-48.

Martinnen, M.L., Suortti, T., Gossenlink, R., Argyropoulos, D.S., Evtuguin, D. Suurnakki, A., de Jong, E., Tamminen, T., 2008. Polymerization of different lignins by laccase. BioResource 3 (2), 549-565.

Matsushita, Y., Yasuda, S., 2005. Preparation and evaluation of lignosulfonates as a dispersant for gypsum paste from acid hydrolysis lignin. Bioresour. Technol. 96 (4), 465-470.

Matsushita, Y., Imai, M., Iwatsuki, A., Fukushima, K., 2008. The relationship between surface tension and the industrial performance of water-soluble polymers prepared from acid hydrolysis lignin, a saccharification by-product from woody materials. Bioresour. Technol. 99 (8), 3024-3028.

Melo, E.P., Fernandes, A.T., Durão, P., Martins, L.O., 2007. Insight into stability of CotA laccase from the spore coat of Bacillus subtilis. Biochem. Soc. Trans. 35 (6), 1579-1582.

Mengual, O., Meunier, G., Cayré, I., Puech, K., Snabre, P., 1999. TURBISCAN MA 2000: multiple light scattering measurement for concentrated emulsion and suspension instability analysis. Talanta $445,456$.

Milstein, O., Hüttermann, A., Ludemann, H.D., Majcherczyk, A., Nicklas, B., 1990 Enzymatic modification of lignin in organic solvents. In: Biotechnology in Pulp and Paper Manufacture. Butterworth-Heinemann, Boston, pp. 375-387.

Milstein, O., Huettermann, A., Frund, R. Luedemann, H., 1994. Enzymic copolymerization of lignin with low-molecular mass compounds. App. Microbiol. Biotechnol. 40 (5), 760-767.

Mohan, S.V., Karthikeyan, J., 1997. Removal of lignin and tannin colour from aqueous solution by adsorption onto activated charcoal. Environ. Pollut. 97, 183-187.

Nugroho Prasetyo, E., Kudanga, T., Steiner, W., Murkovic, M., Nyanhongo, G. Guebitz, G., 2009. Antioxidant activity assay based on laccase-generated radicals. Anal. Bioanal. Chem. 393, 679-687.

Popp, J.L., Kirk, T.K., Dordick, J.S., 1991. Incorporation of p-cresol into lignins via peroxidase-catalysed copolymerization in nonaqueous media. Enzyme Microb. Technol. 13, 964-968.

Ralph, J., Hatfield, R.D., 1991. Pyrolysis-GC/MS characterization of forage materials. J. Agric. Food Chem. 39, 1426-1437.

Ralph, J., Marita, J.M., Ralph, S.A., Hatfield, R.D., Lu, F., Ede, R.M., Peng, J., Quideau, S. Helm, R.F., Grabber, J.H., Kim, H., Jimenez-Monteon, G., Zhang, Y., Jung, H.-J.G., Landucci, L.L., MacKay, J.J., Sederoff, R.R., Chapple, C., Boudet, A.M., 1999. Solution-state NMR of lignin. In: Argyropoulos, D.S. (Ed.), Advances in Lignocellulosics Characterization. Tappi Press, Atlanta, pp. 55-108.

Ralph, J., Lundquist, K., Brunow, G., Lu, F., Kim, H., Schatz, P.F., Marita, J.M., Hatfield, R.D., Ralph, S.A., Christensen, J.H., Boerjan, W., 2004. Lignins: natural polymers from oxidative coupling of 4-hydroxyphenyl-propanoids. Phytochem. Rev. 3 (1) 29-60.

Rebrikov, D.N., Stepanova, E Koroleva, V.O.V. Budarina, Zh.I., Zakharova, M.V. Yurkova, T.V., Solonin, A.S., Belova, O.V., Pozhidaeva, Z.A., Leont'evsky, A.A 2006. Laccase of the lignolytic fungus Trametes hirsuta: purification and characterization of the enzyme, and cloning and primary structure of the gene. Appl. Biochem. Microbiol. 42 (6), 564-572.

Rittstieg, K., Suurnakki, A., Suortti, T., Kruus, K., Guebitz, G.M., Buchert, J., 2002. Investigations on the laccase-catalyzed polymerization of ligninmodel compounds using size-exclusion HPLC. Enzyme Microb. Technol. 31, 403-410.

Robert, D., 1992. Carbon-13 nuclear magnetic resonance. In: Lin, S.Y., Dence, C.W. (Eds.), Methods in Lignin Chemistry. Springer-Verlag, Berlin, pp. 250-273.

Rochefort, D., Leech, D., Bourbonnais, R., 2004. Electron transfer mediator systems for bleaching of paper pulp. Green Chem. 6, 14-24.

Roland, I., Piel, G., Delattre, L., Evrard, B., 2003. Systematic characterization of oil-inwater emulsions for formulation design. Int. J. Pharm. 263 (1-2), 85-94.

Sena-Martins, G., Almeida-Vara, E., Duarte, J.C., 2008. Eco-friendly new products from enzymatically modified lignins. Ind. Crops Prod. 27, 189-195.

Shleev, S., Persson, P., Shumakovich, G., Mazhugo, Y., Yaropolov, A., Ruzgas, T. Gorton, L., 2006. Interaction of fungal laccases and laccase-mediator systems with lignin. Enzyme Microb. Technol. 39 (4), 841-847.

Stewart, D., 2008. Lignin as a base material for materials applications: chemistry, application and economics. Ind. Crops Prod. 27, 202-207.

Tadesse, M.A., D’Annibale, A., Galli, C., Gentilia, P., Sergi, F., 2008. An assessment of the relative contributions of redox and steric issues to laccase specificity towards putative substrates. Org. Biomol. Chem. 6, 868-878.

Thomson, C.I., Lowe, R.M., Ragauskas, A.J., 2005. Excitation energy transfer in cellulosics: indications of inter-fibre fluorescence resonance energy transfer. In: 13th International Symposium on Wood, Forestry, and Pulping Chemistry, Auckland.

Turunen, M.L., Alvila, T., Pakkanen, T.T., Rainio, J., 2003. Modification of phenolformaldehyde resol resin by lignin, starch, and urea. J. Appl. Polym. Sci. 88, 582588.

Vázquez, G., Freire, S., Bona, C.R., Gonźalez, J., Antorrena, G., 1999. Structures and reactivities with formaldehyde, of some acetosolvpine lignins. J. Wood Chem. Technol. 19 (4), 357-378.

Zhang, L.M., Gellerstedt, G., 2007. Quantitative 2D HSQC NMR determination of polymer structures by selecting suitable internal standard references. Magn. Reson. Chem. 45, 37-45. 